Tropical Journal of Pharmaceutical Research November 2015; 14 (11): 1975-1981

ISSN: $1596-5996$ (print); 1596-9827 (electronic)

(c) Pharmacotherapy Group, Faculty of Pharmacy, University of Benin, Benin City, 300001 Nigeria.

All rights reserved.

Available online at http://www.tjpr.org

Original Research Article

http://dx.doi.org/10.4314/tjpr.v14i11.4

\title{
In vitro Anti-Leishmania Activity and Safety of Newly Synthesized Thiazolo Pyrimidine Derivatives Augmented with Interleukine-12 (IL-12) in BALB/c Mice Experimentally- Infected with Cutaneous Leishmaniasis
}

\author{
Saleh A Bahashwan ${ }^{1 *}$, Mohamed A Ramadan², Moutasem S Aboonq ${ }^{3}$ and \\ Ahmed A Fayed ${ }^{4}$ \\ ${ }^{1}$ Pharmacology and Toxicology Department, College of Pharmacy, ${ }^{2}$ Microbiology/Immunology Department, ${ }^{3}$ Physiology \\ Department, College of Medicine, ${ }^{4}$ Respiratory Therapy Department, College of Medical Rehabilitation Sciences, Taibah \\ University, Medina Munawarah, Saudi Arabia
}

*For correspondence: Email: bhswn@yahoo.com; Tel: +966-590045053

Received: 9 May 2015

Revised accepted: 7 October 2015

\begin{abstract}
Purpose: To synthesize a series of novel thiazolo pyrimidine derivatives and evaluate them in vitro and in vivo for their safety and anti-leishmanial activity using BALB/c mice.

Methods: Substituted pyrazolopyrimidine and pyrazolopyrazole were synthesized by reacting amino group of 2-amino-4-cyano-pyrazol]naphthalino[1,2-d]thiazole with a variety of formamide or hydrazine hydrate. The synthesized compounds were characterized by nuclear magnetic resonance spectroscopy ('H-NMR) and mass spectroscopy (MS). The purity of the compounds was determined by elemental analysis. Safety and anti-leishmanial activity of the compounds were determined in vitro by i) viability assessment of leishmania-infected macrophages, relative abundance of IL-12p40 mRNA gene expression and levels of IL $10 / \mathrm{IL}-12$ determination in supernatants of cultured macrophages treated with 2.5 and $10 \mu \mathrm{M}$ of the compounds, using microscope cell counting, reverse transcriptase polymerase chain reaction (RT-PCR) and enzyme linked immunosorbent assay (ELISA), respectively. ii) cytotoxicity of the compounds evaluated by determination the safety index as $I C_{50}$ of the compound in macrophages $/ / C_{50}$ of the compound in amastigotes. iii) bioassay at 16 weeks post-infection of mice treated with the reference drug, the tested compound alone and both the compound with IL-12. Disease progression and footpad thickness were evaluated regularly during treatment.

Results: Compound 4 emerged as the most active anti-protozoal compound of the series against Leishmania viability (activity $60 \%$ ) compared with the reference drug (activity $65 \%$ ). When it was combined with IL-12, the activity reached $90 \%$.

Conclusion: Compound 4 can serve as a lead molecule for further development to a clinically useful novel class of agents.
\end{abstract}

Keywords: Thiazolopyrimidine, Synthesis, Leishmaniasis, Mice, Immunotherapy

Tropical Journal of Pharmaceutical Research is indexed by Science Citation Index (SciSearch), Scopus, International Pharmaceutical Abstract, Chemical Abstracts, Embase, Index Copernicus, EBSCO, African Index Medicus, JournalSeek, Journal Citation Reports/Science Edition, Directory of Open Access Journals (DOAJ), African Journal Online, Bioline International, Open-J-Gate and Pharmacy Abstracts

\section{INTRODUCTION}

Leishmaniasis, caused by the protozoan parasite of the genus Leishmania, affects over 12 million individuals worldwide, $1.5-2$ million of whom develop symptomatic disease every year [1]. The parasite is spread by the sand fly vector and causes a spectrum of diseases depending on the 
parasite species and the host immune status. Clinical manifestations of the disease range from self-limiting cutaneous Leishmaniasis, disfiguring muco-cutaneous Leishmaniasis, to fatal visceral leishmaiasis. Current treatment use toxic antimonial compounds. These treatments are laborious and expensive, cause severe side effects and emerging drug resistance has been reported [2]. Therefore, an alternative effective treatment regime would be desirable.

Immunity against L. major infection is well characterized in the mouse model and depends mainly on T-helper1 (Th1) immune responses mediated by $\mathrm{CD}^{+} \mathrm{T}$ cells induced by the essential cytokine IL-12 [3]. As Leishmania reside within macrophages, they deviously manipulate the host innate and acquired immune mechanisms. This ensures their survival within the hostile environment of macrophages and hinges on their capacity to modulate macrophage effect or functions including production of reactive nitrogen intermediates, RNI [4]. Macrophages can induce host cells to produce cytokines that promote disease progression via regulation of Th1 and Th2 cells. The Th1 cells by secreting IFN- $\delta$ enhance macrophage microbial activity, thus protecting the host from intracellular Leishmania pathogens [5]. Conversely, the parasite for survival cleverly augments Th2 response, leading to an increased secretion of IL-4 and IL-10, resulting in attenuation of the host mechanisms and Leishmania infection ensues [6].
Newly synthesized pyrimidine and pyrazolo derivatives are well documented $[7,8]$. Hetero cyclic compounds exhibit anthelmintic, anti HIV activity and hypoglycemic activity [9], antimicrobial, analgesic [10,11], against herpes simplex virus type-1 (HSV-1) and hepatitis-A virus (HAV), serotonin 5-HT6 receptor antagonist [12], antitumor activity and anticancer activity [13]. Thiazolopyrimidines have hypoglycemic, hypolipidemic, anti-diabetic, [14] and antimalarial $[15,16]$. As an extension of our ongoing studies, the objective of the present work is to synthesize new compounds and evaluates them both in vitro and in vivo for their anti-protozoal activities against experimental cutaneous Leishmaniasis in mice.

\section{EXPERIMENTAL}

In a previous work, we have reported the synthesis of substituted pyrazolopyrimidine 3 and pyrazolopyrazole 4 by using 1-(naphtho[1,2d]thiazol-2-yl)hydrazine 1 as starting material. The starting material 1 was synthesized according to the previous procedure [17] (Scheme 1).

The reaction of compound 1 with ethoxymethylene malomonitrile afforded the corresponding 3-amino-4-cyanopyrazolo derivatives 2, which was treated with formamide or hydrazine hydrate to produce the corresponding 3-aminopyrazolopyrimidine 3 and aminopyrazolopyrazole derivative 4 , respectively [18] (Scheme 2).

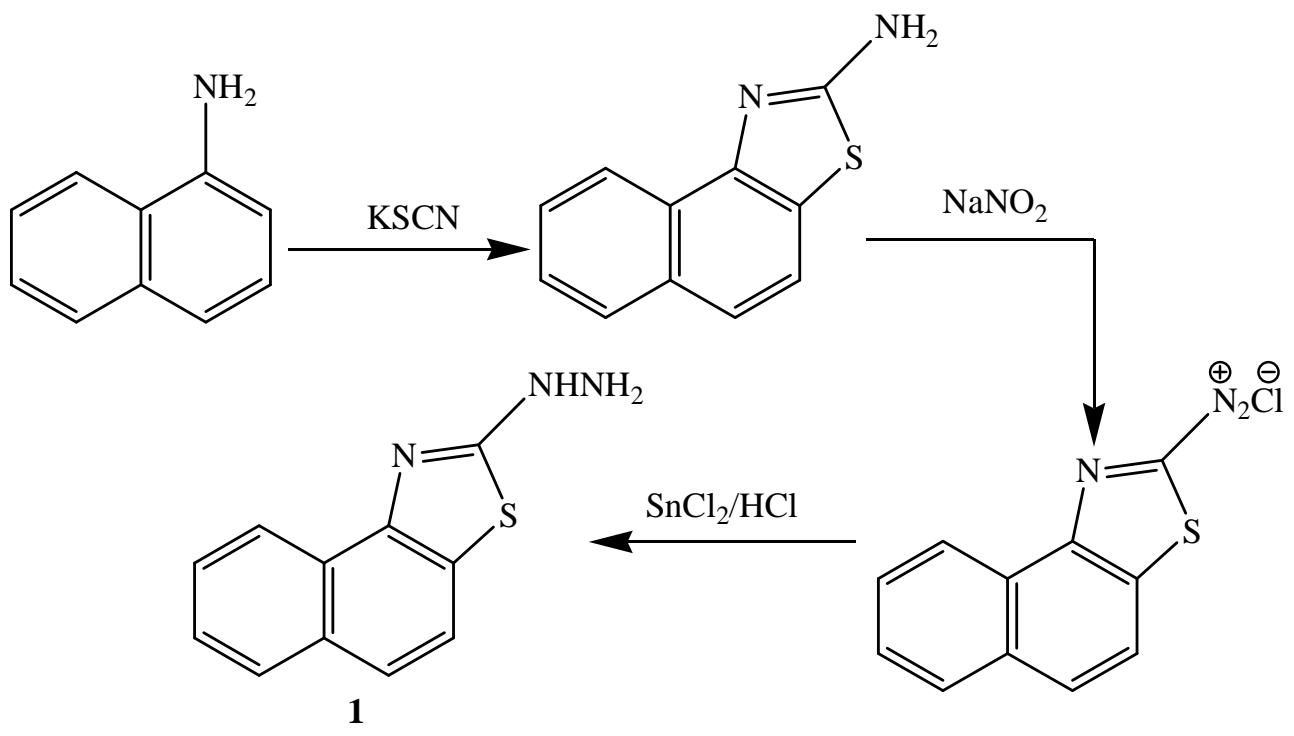

Scheme 1: Synthetic route of 1-(naphtho[1,2-d]thiazol-2-yl)hydrazine 1 


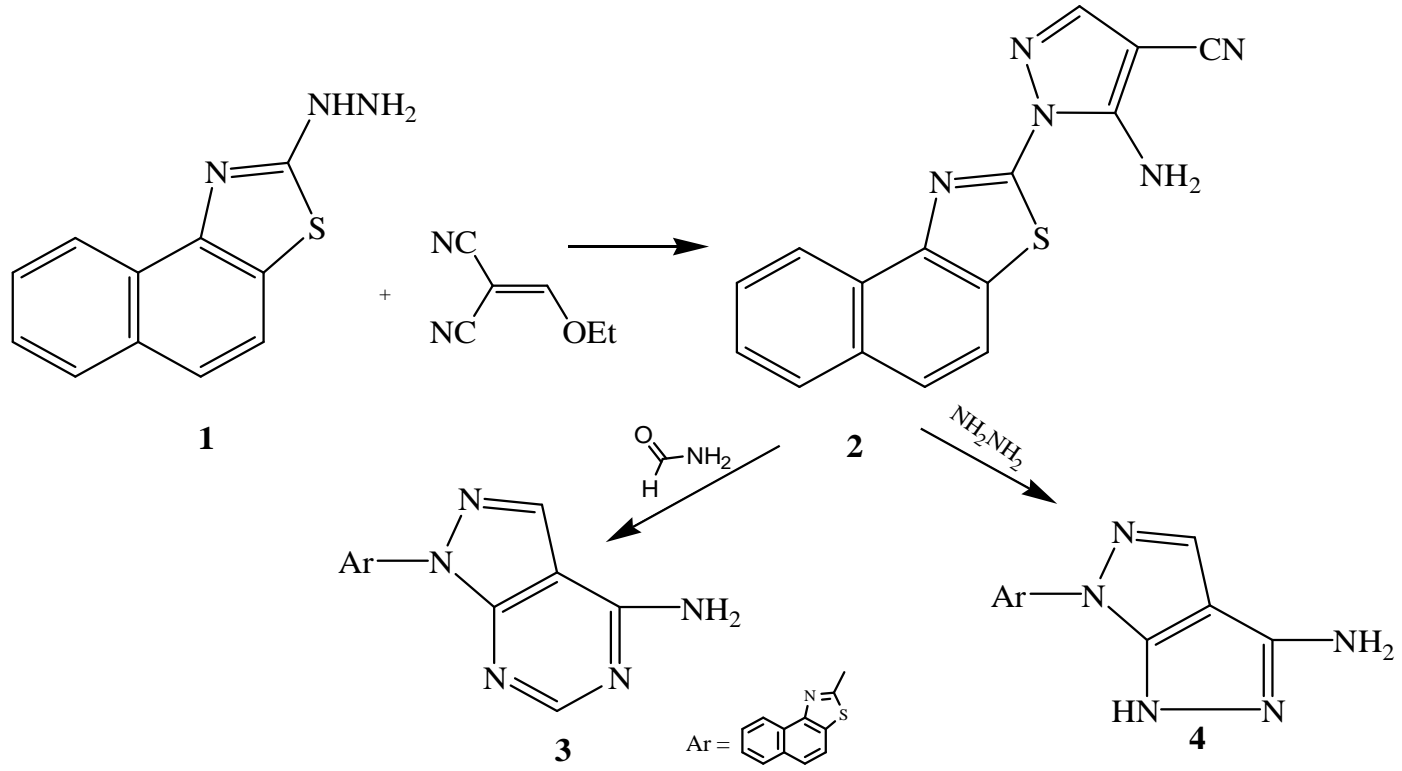

Scheme 2: Synthetic route of compounds 2-4

\section{Synthesis of 2-[3-amino-4-cyano-pyrazol-2-yl] naphthalino [1,2-d]thiazole (2)}

A mixture of compound $1(0.01 \mathrm{~mol})$ and ethoxymethylene malononitrile $(0.01 \mathrm{~mol})$ in absolute ethanol $(30 \mathrm{~mL})$ was refluxed for $2 \mathrm{~h}$. The solvent was evaporated under reduced pressure; the residual solid was crystallized from ethanol to give the title product $\mathbf{2}$ as yellow powder. Yield $87 \%$; m.p. $256-258{ }^{\circ} \mathrm{C}$; IR $(\mathrm{KBr}$, $\left.\mathrm{cm}^{-1}\right): 3345-3315\left(\mathrm{NH}_{2}\right)$ and $2215(\mathrm{CN}) \mathrm{cm}^{-1} ;{ }^{1} \mathrm{H}-$ NMR $\left(\right.$ DMSO- $\left.\mathrm{d}_{6}\right): \delta=6.78-7.61(\mathrm{~m}, 7 \mathrm{H}, 6 \mathrm{Ar}-\mathrm{H}$ and $\left.1 \mathrm{H}_{\text {Pyrazolo }}\right)$ and 10.43 (b, $2 \mathrm{H}, \quad \mathrm{NH}_{2}$ exchangeable with $\mathrm{D}_{2} \mathrm{O}$ ) ppm; MS m/z (\%) = 291 $\left(\mathrm{M}^{+}, 23\right)$ corresponding to the molecular formula $\mathrm{C}_{15} \mathrm{H}_{9} \mathrm{~N}_{5} \mathrm{~S}$ and at 184 (100, base peak).

\section{Synthesis of 2-[6-aminopyrimidino[4,5-} c]pyrazol-2-yl]naphthalino[1,2-d]thiazole (3)

A solution of compound $2(0.01 \mathrm{~mol})$ in formamide $(20 \mathrm{ml})$ was refluxed for $2 \mathrm{~h}$. After cooling, the solid product was collected by filtration, dried and crystallized from methanol to give the title product $\mathbf{3}$ as reddish brown powder Yield $66 \%$; m.p. $290-292{ }^{\circ} \mathrm{C}$; IR $\left(\mathrm{KBr}, \mathrm{cm}^{-1}\right)$ : $3325\left(\mathrm{NH}_{2}\right) \mathrm{cm}^{-1} ;{ }^{1} \mathrm{H}-\mathrm{NMR}$ (DMSO-d $\left.\mathrm{d}_{6}\right): \delta=6.64-$ $7.52\left(\mathrm{~m}, 8 \mathrm{H}, 6 \mathrm{Ar}-\mathrm{H}, 1 \mathrm{H}_{\text {pyrazolo }}\right.$ and $\left.1 \mathrm{H}_{\text {Pyrimidino }}\right)$ and $11.12\left(\mathrm{~b}, 2 \mathrm{H}, \mathrm{NH}_{2}\right.$ exchangeable with $\mathrm{D}_{2} \mathrm{O}$ ) ppm; MS $\mathrm{m} / \mathrm{z}(\%)=318\left(\mathrm{M}^{+}, 19\right)$ corresponding to the molecular formula $\mathrm{C}_{16} \mathrm{H}_{10} \mathrm{~N}_{6} \mathrm{~S}$ and at 120 (100, base peak).

\section{Synthesis of 2-[5-amino-3H-pyrazolo[3,4- c]pyrazol-2-yl]naphthalino[1,2-d]thiazole (4)}

A mixture of compound $2(0.01 \mathrm{~mol})$, and hydrazine hydrate $(0.01 \mathrm{~mol})$ in acetic acid (30
$\mathrm{mL}$ ) was refluxed for $3 \mathrm{~h}$. The reaction mixture was poured onto ice cold water. The solid was filtered off, dried and crystallized from ethanol to give title product 4 as green powder. Yield $69 \%$; $\mathrm{mp}>300{ }^{\circ} \mathrm{C}$; IR $\left(\mathrm{KBr}, \mathrm{cm}^{-1}\right): 3372-3323(\mathrm{NH}$, $\left.\mathrm{NH}_{2}\right) \mathrm{cm}^{-1} ;{ }^{1} \mathrm{H}-\mathrm{NMR}$ (DMSO-d $\left.\mathrm{d}_{6}\right): \delta=6.15(\mathrm{~s}, 1 \mathrm{H}$, $\mathrm{NH}$ exchangeable with $\left.\mathrm{D}_{2} \mathrm{O}\right), 7.21-7.58(\mathrm{~m}, 7 \mathrm{H}$, $6 \mathrm{Ar}-\mathrm{H}$ and $\left.1 \mathrm{H}_{\text {Pyrazolo }}\right)$ and $11.42\left(\mathrm{~b}, 2 \mathrm{H}, \mathrm{NH}_{2}\right.$ exchangeable with $\left.\mathrm{D}_{2} \mathrm{O}\right) \mathrm{ppm}$; $\mathrm{MS} \mathrm{m} / \mathrm{z}(\%)=306$ $\left(\mathrm{M}^{+}, 31\right)$ corresponding to the molecular formula $\mathrm{C}_{15} \mathrm{H}_{10} \mathrm{~N}_{6} \mathrm{~S}$ and at 184 (100, base peak).

\section{Animals}

Five to 6- week- old BALB/c mice of either sex, 16-18 g each were purchased from Theodor Bilharz Research Institute TBRI, Egypt. Approval of the institutional Animal Ethical Committee for the animal studies was obtained from the Office of Environmental Health and Radiation Safety (ACUC protocol \# 1096-5). The animals were maintained according to accepted standards of human care [19]

\section{Parasite culture}

Promastigotes from Indian Leishmania donovani isolate (NS2) were routinely passaged in mice and after transformation, cultured at $24{ }^{\circ} \mathrm{C}$ in medium 199 supplemented with $10 \%$ heat inactivated fetal calf serum (HIFCS), Penicillin G $(50 \mathrm{IU} / \mathrm{mL})$ and Streptomycin $(50 \mu \mathrm{g} / \mathrm{mL})$. For infection of macrophages, $24 \mathrm{~h}$ prior to the experiment, stationary phase promastigotes were centrifuged and the pellet re-suspended in Schneider's insect medium supplemented with $20 \%$ HIFCS, pH 5.5, as described by [20] 


\section{In vitro anti-amastigote activity in macrophages}

Peritoneal macrophages lavaged from BALB/C mice were seeded in 16 chamber slides $(1.5 \mathrm{x}$ $10^{5} / 200 \mu \mathrm{l} /$ well of complete RPMI-1640 medium) and after a 2 - $4 \mathrm{~h}$ incubation at $37{ }^{\circ} \mathrm{C}, 5 \% \mathrm{CO}_{2}$, the supernatants (containing lymphocytes) were gently removed and kept aside at $37{ }^{\circ} \mathrm{C}, 5 \%$ $\mathrm{CO}_{2}$. Adherent macrophages were then infected with stationary phase $L$. donovani promastigotes (preconditioned at $25{ }^{\circ} \mathrm{C}$ for $24 \mathrm{~h}$ in Schneider's insect medium $\mathrm{pH} 5.5$ at a macrophage: parasite ratio of $1: 10$ and incubated for $5 \mathrm{~h}$ at $37^{\circ} \mathrm{C}, 5 \%$ $\mathrm{CO}_{2}$. After removal of non-internalized parasite, macrophages were then co-cultured with the above mentioned supernatants in the presence or absence of compound 3 and compound 4 separately at a dose of $(0-25 \mu \mathrm{M})$ for $72 \mathrm{~h}$, after which cells were fixed., Giemsa-stained (diluted $1: 7$ in deionized water, $\mathrm{pH}$ 6.8) and examined microscopically for intracellular amastigotes. At least 100 macrophages/well were counted to calculate the percentage of infected macrophages. The infection rate of treated macrophages was normalized to $100 \%$ for further analysis.

\section{Safety index of the synthetic compounds}

To investigate the cytotoxicity of the compounds, murine macrophages $\left(1.5 \times 10^{5} / 200 \mu \mathrm{l} /\right.$ well $)$ were incubated with the compounds $(0-100 \mu \mathrm{M})$ at 37 ${ }^{\circ} \mathrm{C}, 5 \% \mathrm{CO}_{2}$ for 48,72 and $96 \mathrm{~h}$ and cell viability enumerated as described by [21]. The safety index was calculated as the $\mathrm{IC}_{50}$ of the compound in macrophages/ $\mathrm{IC}_{50}$ of compound in amastigotes.

\section{Reverse transcriptase polymerase Chain reaction (RT-PCR)}

Total RNA was isolated using the RNAqueous Kit from normal and Leishmania-infected macrophages (obtained from BALB/c mice) after being treated the tested compound (2.5 and 10 $\mu \mathrm{M})$ for $18 \mathrm{~h}$. Subsequently, RT-PCR was carried out with the one-step RT-PCR kit using (200 $\mathrm{ng} /$ reaction) that was reverse-transcribed into cDNA and amplified, using gene-specific primers as described previously [22].

\section{IL-10 and IL-12 measurement using sandwich ELISA}

Levels of mouse IL-10 and IL-12p40 present in the supernatants of uninfected and $L$. donovani infected macrophages that had been treated with the compounds for $24 \mathrm{~h}$ were measured using an ELISA kit as per the manufacturer's instruction. A standard curve with a cytokine-positive control was run in each assay, the lower limit of detection being $31.24 \mathrm{pg} / \mathrm{mL}$ for $\mathrm{IL}-10$ and 15.0 $\mathrm{pg} / \mathrm{mL}$ for IL-12p40.

\section{Parasite Infection and tissue studies}

Mice were inoculated in one hind footpad with metacyclic promastigotes. A total of $1-2 \times 10^{5}$ highly infective stage metacyclic promastigotes was isolated from stationary culture (5-7 d old) by negative selection using peanut agglutinin (Vector laboratories, Burlingame, CA) and injected subcutaneously in the left footpad. The infected footpad was kept under observation 16 weeks after infection for redness, swelling, ulceration, crust formation or gangrenous changes. The evolution of the lesion was monitored weekly by measuring footpad thickness using metric caliper (Mitutoyo Measuring Instruments, Aurora, IL). The degree of infection in parasitized footpad lesions was determined by limiting dilution analysis of homogenized tissue. To determine parasite concentrations, footpads were weighed and homogenized. Two-fold serial dilutions of the homogenized tissue suspensions were then plated in 96-well plates and incubated at $26{ }^{\circ} \mathrm{C}$ for 7-10 days. Wells were examined for viable and motile promastigotes, and the highest dilution that was positive for parasites was considered to be the parasite concentration per milligram of tissue. The total parasite burden was calculated using the weight of the footpad, as previously described [23].

\section{Animal's treatment regime}

Sodium stibogluconate (Pentostam, Burroughs Welcome, London, United Kingdom) containing $100 \mathrm{mg}$ of pentovalent antimony per $\mathrm{ml}$ ) was a gift of Max Grog, Walter Reed Army Institute of Research, Washington, D.C. Mouse recombinant IL-12, kindly provided by Giorgio Trinchieri (Wistar Institute, Philadelphia, PA). Animals were divided into experimental groups (GPs), 45 mice each, GP1: untreated infected control, received intradermal injection of $2 \times 10^{7}$ viable promastigotes in the right footpad; GP2: Infected and treated with the reference drug (Sodium stibogluconate), each mice received a total of 10 daily intramuscular injections with $250 \mathrm{mg}$ of drug per $\mathrm{kg}$ of body weight during weeks 3 and 4 of infection; GP3: infected and treated with compound 4 , each mice received a total of 10 daily intramuscular injections with $25 \mathrm{mg}$ of the compound per $\mathrm{kg}$ of body weight during weeks 3 and 4 of infection; GP4: infected and treated with compound 4 as mentioned before + IL-12 (0.1 $\mathrm{mL}$ containing $0.1 \mu \mathrm{g}$ of $\mathrm{IL}-12$ ) intraperitoneally 
on day 15 of infection with an additional dose on day 22 of infection. One group was used as normal non-infected control, injected with $0.1 \mathrm{~mL}$ sterile saline in the right hind footpad.

\section{Statistical analysis}

The results are expressed as mean \pm SD/SEM as indicated. Statistical analysis was based on oneway ANOVA followed by Turkey's Multiple Comparison Test using Graph Pad Prism software, version $4 . P<0.05$ was considered as statistically significant.

\section{RESULTS}

\section{Anti-leishmanial activity of the synthesized compounds}

The anti-leishmanial activity of the synthetic compounds $(0-25 \mu \mathrm{M})$ was evaluated in terms of the intracellular parasite load, wherein the infection rate of Leishmania infected macrophages was normalized to $100 \%$; with the addition of the tested compound, a dose dependent reduction in parasitic load was evident, the $\mathrm{IC}_{50}$ being $2.5 \mu \mathrm{M}$ (Fig. 1). In macrophages, $92 \%$ were parasitized and the average number of amastigotes/macrophage was 11.3. After treatment with the tested compound $(72 \mathrm{~h})$, the percentage of infected macrophages decreased in a dose-dependent manner. With $10 \mu \mathrm{M}$ of the compound, only $59 \%$ of macrophages were infected, the number of amastigotes/macrophage being 1.7 .

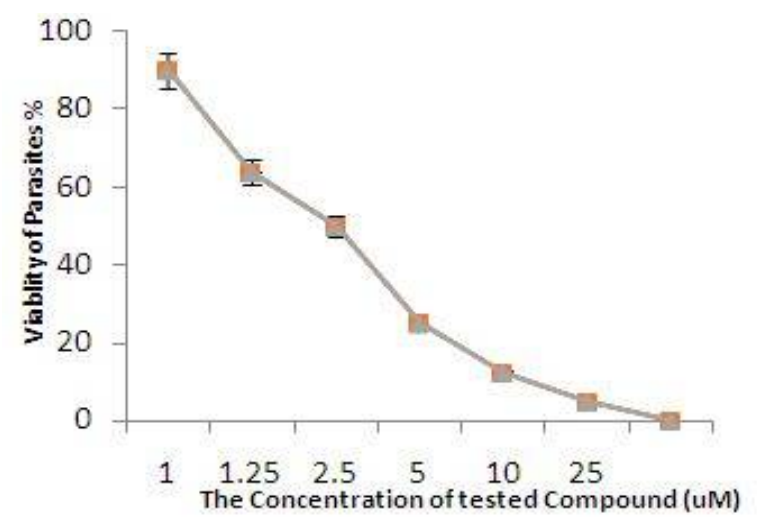

Figure 1: Anti-amastigote activity and safety index of the tested compound. Each point corresponds to the mean \pm SD of at least three experiments in duplicate

The synthetic compounds enhanced mRNA
expression of IL-12p40

In uninfected macrophages, the tested compound $(2.5$ and $10 \mu \mathrm{M})$ induced an increase in mRNA expression of IL-12p40. Following infection with Leishmania parasites (as confirmed by Giemsa staining), a down regulation in mRNA expression of IL-12p40 was observed, which was reversed by the tested compound (Fig. 2).

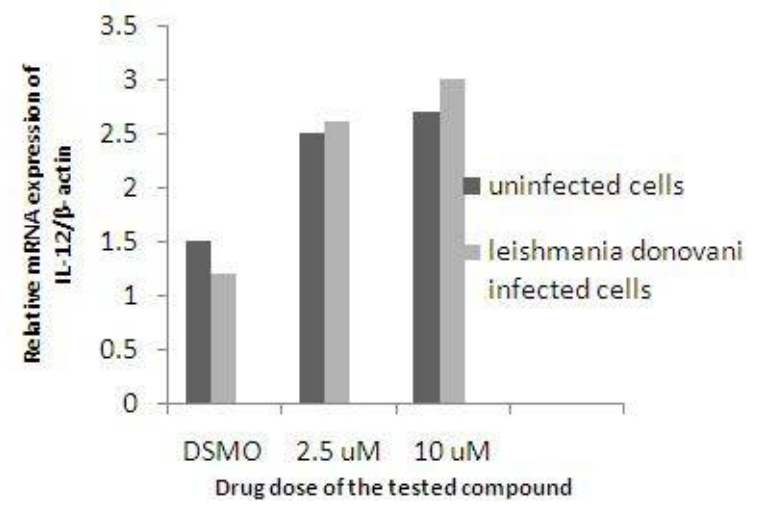

Figure 2: Effect of the tested compound on mRNA gene expression of IL-12p40 in macrophages

This genetic up-regulation of IL-12p40 by the tested compound was correlated by quantifying levels in culture supernatants by ELISA. In uninfected macrophages, the mean \pm SEM was $495.00 \pm 26.53 \mathrm{pg} / \mathrm{mL}$, which with the tested compound $(2.5$ and $10 \mu \mathrm{M})$ significantly increased by 1.85 and 1.9 fold $(p<0.001)$ respectively. Following successful intracellular Leishmania infection, levels of IL-12 reduced significantly by 1.7 fold, $(p<0.001)$, importantly, treatment with the synthetic compound (2.5 and $10 \mu \mathrm{M})$ significantly increased production of IL$12 \mathrm{p} 40$ to $550.8 \pm 60.5(p<0.05)$ and $595.1 \pm$ $32.98 \mathrm{pg} / \mathrm{mL}(p<0.01)$ respectively compared with infected macrophages (Fig. 3).The tested compound (2.5 and $10 \mu \mathrm{M})$, significantly decreased the secretion of IL-10 as compared with the infected macrophages (data not shown).

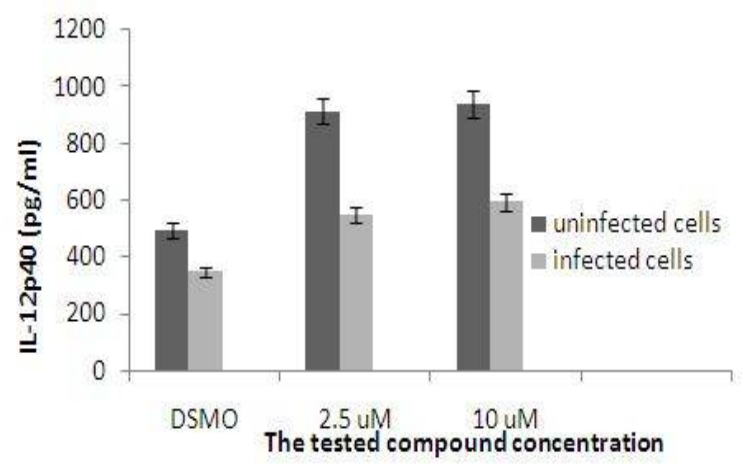

Figure 3: Effect of the tested compound on IL-12p40 level in macrophages culture supernatants Each point represents the mean \pm SEM of IL-12p40 (pg/mL) of at least 3 experiments in duplicate

Trop J Pharm Res, November 2015; 14(11): 1979 


\section{Cutaneous lesion and the parasitological footpad tissue studies}

Early onset was observed in the infected control group (GP1), where swelling, ulceration and gangrene formation were observed in the majority of mice and the lesion developed up to total gangrene and auto-amputation. Later onset was observed in the reference drug treated group (GP2), up to ulceration with minority of mice developed gangrene and only 2 mice developed auto-amputation. Also, the latest onset was observed in the compound 4 treated group (GP3) and the combination treated group (GP4) up to ulceration with no gangrene or amputation, where the ulcers were slow developing, healing and only observed in the minority of mice as shown in (Table 1). There was a dramatic lessening of disease progression, as seen by reduction of footpad swelling in mice treated with the compound 4 combined with IL-12 compared with the infected control group, (data not shown).

\section{DISCUSSION}

In a previous work, we have reported the synthesis of pyrazolopyrimidine and pyrazolopyrazole derivatives using hydrazinothiazole 1 as starting material. The reaction of a-amino naphthol with $\mathrm{KSCN}$ produced 2 amino thiazolo derivatives. The reaction of 2-amino thiazolo derivatives with sodium nitrite and hydrochloric acid produced the corresponding diazoium salt, which converted to 2- hydrazine thiazolo derivatives 1 (Scheme 1). Reaction of hydrazinothiazolo derivatives 1 with ethoxymethylene afforded compound 2, which reacted to formamide and hydrazine hydrate respectively to produce pyrazolopyrimidine $\mathbf{3}$ and pyrazolopyrazole 4 respectively (Scheme 2). All the synthesized compounds were confirmed by spectral data (IR, ${ }^{1} \mathrm{H}$-NMR and mass spectra). Structure-activity relationships based on the obtained results indicated that substitution of 2[6-aminopyrimidino[4,5-c]pyrazol-2-yl]naphthalino [1,2-d]thiazole 3 derivatives had anti-leishmanial activity and safety effect.

We initially investigated whether the new synthetic compounds $\mathbf{3}$ and $\mathbf{4}$ affect the amastigote activity inside Leishmania infected macrophages and affect the IL-12 mRNA gene expression with IL-10, IL-12 cytokines secretion levels. In uninfected macrophages, the tested compounds ( 2.5 and $10 \mu \mathrm{M}$ ) induced an increase of IL-12p40 mRNA gene expression. Following infection with Leishmania parasite a downregulation of this protein was observed, which was reversed by our new synthetic compounds. This genetic up-regulation was correlated with the increased levels of IL-12 after treatment of infected macrophages with the compounds.

Animal studies showed that compound $\mathbf{4}$ treated group (GP3) achieved a maximum delayed onset of cutaneous Leishmaniasis disease progression with a decrease of footpad thickness and parasite density in the infected footpad compared with the infected control group (GP1), specifically when combined with the immunotherapeutic agent IL-12 (GP4). Our results showed the antileishmanial activity of the synthetic compounds were in consistence with previous results showed that hetero-cyclic compounds were potent anthelmintic, anti-fungal and anti-malarial agents [10-16]

\section{CONCLUSION}

The results indicate that the synthesized heterocyclic organic compounds, a new series of substituted pyrazolopyrimidine $\mathbf{3}$ and pyrazolopyrazole 4 , are promising agents for the development of new antiprotozoal candidates for enhanced safety and pharmacological efficacy when augmented with immunotherapy IL-12 for the treatment of cutaneous leishmaniasis.

Table 1: Onset of cutaneous lesion development in different studied groups (Note: number of mice in parenthesis)

\begin{tabular}{lcccccc}
\hline $\begin{array}{l}\text { Animal } \\
\text { group }\end{array}$ & Redness & Swelling & Ulceration & $\begin{array}{c}\text { Partial gangrene } \\
\text { (No. of mice) }\end{array}$ & $\begin{array}{c}\text { Total gangrene } \\
\text { (No. of mice) }\end{array}$ & Auto-amputation \\
\hline GP1 & $7^{\text {th }}$ day & $10^{\text {th }}$ day & 5 wks $(45)$ & 10 wks $(35)$ & 12 wks $(42)$ & 14 wks $(40)$ \\
GP2 & $10^{\text {th }}$ day & $14^{\text {th }}$ day & 6 wks $(25)$ & 12 wks $(15)$ & 14 wks $(10)$ & 16 wks $(2)$ \\
GP3 & $17^{\text {th }}$ day & $24^{\text {th }}$ day & 8 wks $(10)$ & None & None & None \\
GP4 & $20^{\text {th }}$ day & $28^{\text {th }}$ day & 9 wks (5) & None & None & None \\
\hline
\end{tabular}

GP1 = infected control; GP2 = Infected and treated with the reference drug; GP3= Infected and treated with compound 4; GP4= Infected and treated with both compound 4 and IL-12 


\section{ACKNOWLEDGEMENT}

This work was fully supported by the Scientific Research Deanship, Taibah University, Ministry of Higher Education, Saudi Arabia (Grant \# 3084/434). The authors are grateful to Taibah University President and the Dean of Scientific Research for their support.

\section{REFERENCES}

1. Ameen M. Cutaneous leishmaniasis, advances in disease pathogenesis, diagnosis and therapeutics. Clin Exp Dermatol 2010; 35: 699-705.

2. Ait-Oudhia K, Gazanion E, Vergnes B, Oury B, Sereno D. Leishmania antimony resistance: what we know what we can learn from the field. Parasitol Res 2011; 109(5): 1225-1232.

3. Mougneau E, Bihl F, Glaichenhaus N. Cell biology and immunology of Leishmania. Immunol Rev 2011; 240: 286-296.

4. Nadeer T, McConville MJ. The Leishmania-macrophage interaction: a metabolic perspective. Cell Microbiol 2008; 10: 301-308.

5. Roberts MT. Current understanding on the immunology of Leishmaniasis and recent developments in prevention and treatment. Br Med Bull 2006; 75-76: 115-130.

6. Kane MM, Moser DM. The role of $I L-10$ in promoting disease progression in Leishmaniasis. $J$ Immunol 2001; 166: 1141-1147.

7. Namazi $H$, Mirzaei YR, Azamat $H$. Investigation the Chemical Reactivity of Positions N-3, C-5 and C-6Methyl Group in Biginelli type Compounds and Synthesis of New Dihydropyrimidine Derivatives. J Hetero Chem 2001; 38(5): 1051-1054.

8. Kheder NA, Mabkhot YN, Farag AM. A convenient access to new pyrido[4,3-d]pyrimidine,thiazolo[3,4c]pyrimidine and pyrimido[4,5-d]pyridazine derivatives. Arkivoc 2008; 17: 107-116.

9. Rao A, Balzarini J, Cafbone A, Chimirri A. 2-(2,6Dihalophenyl)-3-(pyrimidin-2-yl)-1,3-thiazolidin-4ones as non-nucleoside HIV-1 reverse transcriptase inhibitors. Antiviral Res 2004; 63(2): 79-84.

10. Fayed AA, Hosni HM, Flefel EM, Amr AE. Synthesis and Pharmacological Activity of Some New Thino Pyrimidine and Pyrimido pyrazolo thino pyrimidine Derivatives. W J Chem 2009; 4(1): 58-65.

11. Bahashwan SA. Pharmacological studies of some pyrimidino derivatives. Afri J Pharm and Pharmacol $2011 ; 5(4): 527-531$

12. Ramakrishna VS, Kambhampati RS, Kothmirkar $P$, Arepalli S, Reddy GN. Convenient and Efficient
Synthesis of Some Novel Fused Thieno Pyrimidines Using Gewald's Reaction. Synth Comm 2011; 41(19): 2835-2851.

13. Abdel-hafez NA, Mohamed AM, Amr AE, Abdalla MM. Antiarrhythmic Activities of Some Newly Synthesized Tricyclic and Tetracyclic Thienopyridine Derivatives. Sci Pharm 2009; 77: 539-553.

14. Lee HW, Kim BY, Ahn JB, Kang SK, Lee JH, Shin JS, Ahn SK, Lee SJ, Yoon SS. Molecular design, synthesis, and hypoglycemic and hypolipidemic activities of novel pyrimidine derivatives having thiazolidinedione. Eur J Med Chem 2005; 40(9): 862874.

15. Sunny MS, Chinna Rajesh UC, Khan SI, Tekwani BL, Rawat DS. Novel 4-Aminoquinoline-Pyrimidine Based Hybrids with Improved in Vitro and in Vivo Antimalarial Activity. ACS Med Chem Lett 2012; 3(7): 555-559.

16. Christian DJ, Bhoi MN, Mayuri A, Borad MA, Rajani DP, Rajani SD, Patel HD. Microwave Assisted Synthesis and in Vitro Anti-malarial Screening of Novel Pyrimidine Derivatives. W J Pharm Pharmaceut Sci 2014; 3(8): 1955-1971.

17. Fayed $A A$ and Ghanem $S$. Anti-microbial evaluation of new thiazolo pyrimidine derivatives. Eur Sci J 2013; 9 (33): 1857-7881.

18. Bahashwan SA, Fayed AA, Ramadan MA, Amr AE, AlHarbi NO. Androgen Receptor Antagonists and AntiProstate Cancer Activities of Some Newly Synthesized Substituted Fused Pyrazolo-, Triazoloand Thiazolopyrimidine Derivatives. Int $J \mathrm{Mol}$ Sci 2014; 15(11): 21587-21602.

19. Mahmoud AAF. In: Tropical and Geographical Medicine, McGraw-Hill, New York, 1984; p 443.

20. Da Luz RI, Vermeersch $M$, Dujardin JC, Cos $P$, Maes $L$. In vitro sensitivity testing of Leishmania clinical field isolates: preconditioning of promastigotes enhances infectivity for macrophages host cells. Antimicrob Agents Chemother 2009; 53: 5197-5203.

21. Ganguly S, Bandyopadhyay S, Sakar A. Development of a semi-automated colorimetric assay for screening anti-leishmanial agents. J Microbiol Methods 2006; 66: 79-86.

22. Ganguly S, Mula S, Chattopadhyaz S, Chatterjee M. An ethanol extract of piper betleLinn. Mediates its antiinflammatory activity via down-regulation of nitric oxide. J Pharm Pharmacol 2007; 59: 711-718.

23. Raman VS, Bhatia A, Picon A, Whittle J, Bailor HR, O'Donnell J, Pattabhi S, Guderian JA, Mohamath R, Duthie MS, Reed SG. Applying TLR Synergy in Immunotherapy: Implications in Cutaneous Leishmaniasis J Immunol 2010; 185: 1701-1710. 